\title{
https://doi.org/10.46813/2021-133-128 \\ APPLICATION OF EXPERT SYSTEMS FOR DETERMINING THE SIZE OF THE SANITARY PROTECTION ZONE OF NUCLEAR FACILITY
}

\author{
S.V. Barbashev \\ Odessa National Polytechnic University, Odessa, Ukraine \\ E-mail: josik65@gmail.com
}

\begin{abstract}
The dimensions of the sanitary protection zones (SPZ) for nuclear facility (NF) of I and II hazard classes are calculated based on the recommendations of national regulatory documents, taking into account the radiation factor of human exposure. At the same time, factors of a non-radiation nature are not considered, although they are present in the zone of influence of the NF and make an additional contribution to the formation of negative consequences for people. In this case, the definition of the boundaries of the SPZ is possible only in a result of analysis, comparison and calculation of various values characterizing the state of the environment and NF. Such an opportunity can be provided by the use of an expert system. The article describes a simplified version of the expert system designed to determine the boundaries of the NPP SPZ, which takes into account the dose criterion and criteria for non-radiation factors, and the results of its application for a real NPP.
\end{abstract}

PACS: 87.52.-g

\section{INTRODUCTION}

In accordance with the "Basic Sanitary Rules for Ensuring Radiation Safety of Ukraine" [1] for nuclear physics installations (NF) of I and II hazard classes, special protective areas are mandatory - sanitary protection zones (SPZ), which, by their functional purpose are a protective barrier that ensures the safety of the population under various operating modes of the nuclear power plant $[1,2]$.

The I hazard class includes enterprises that have nuclear power plants, during normal operation of which or in case of an accident, radiation exposure to the population is possible. These include nuclear power plants, facilities with industrial and research nuclear reactors, transport nuclear installations, critical assemblies, enterprises for the extraction and processing of uranium ores, radiochemical plants, enterprises for the processing of nuclear materials, enterprises for the processing and disposal of radioactive waste.

The II class of hazard includes enterprises where the radiation impact is limited by the SPZ. This category of facilities includes institutions that have accelerators for protons and other heavy particles, as well as accelerators for electrons with an energy of more than $25 \mathrm{MeV}$, powerful gamma installations, enterprises for the production of products from unenriched uranium, disposal facilities and low-level waste processing facilities.

It should be said that at present, the requirements for the mandatory establishment of SPZ exist mainly in the states - the former republics of the USSR, in which nuclear power plants and other nuclear installations are operated. At the world's leading nuclear power plants developing nuclear power, the establishment of SPZs during normal operation of power units is not provided. The very concept of SPZ is absent in the IAEA standards and ICRP recommendations.

In contrast to the approach taken in Ukraine and other post-Soviet countries, the IAEA recommends the establishment not of a SPZ, but of the so-called emergency planning zones, consisting of a precautionary action zone and a urgent protective action planning zone to ensure availability and response in the event of a nuclear or radiation accident. The sizes of these zones are established by the emergency management plans taking into account the situation in the territory around the NF after the nuclear or radiation accident [3].

In both cases, the size of the protection zones is established on the basis of appropriate criteria limiting the exposure of the public outside the NF site. If the IAEA recommendations consider only emergencies, then national regulatory documents recommend setting the size of the SPZ taking into account the limitation of the amount of radiation exposure, both during normal operation and in case of violations of normal operation, incl. in case of design basis and beyond design basis accidents. In this case, the calculations should take into account a number of factors and parameters describing both the characteristics of the nuclear installation and the radiation state of the environment in the area of the NF location under the corresponding operating modes.

The dimensions of the SPZ for enterprises of I and II hazard classes are established based on the results of calculations recommended by national regulatory documents, taking into account only the radiation factor of impact on the environment and humans, the level of which is determined on the basis of the dose criterion [4]. In this case, factors of a non-radiation nature are not considered. However, as studies have shown, such factors, together with ionizing radiation (combined exposure), can increase the likelihood of negative consequences from radiation exposure to humans, i.e. increase the amount of radiation risk. In this case, when determining the size of the SPZ of a nuclear power plant, it will be necessary to introduce additional criteria for non-radiation factors to the dose criterion.

It follows from what has been said that the definition of the boundaries of the SPZ becomes possible in a result of analysis, calculation and comparison of not only radiation parameters characterizing the state of the environment and the characteristics of the nuclear power plant, but also the parameters that describe the influence of various factors of a non-radiation nature. In this case, choosing the optimal solution based on the analysis of a large number of parameters, some of which are not always quantified, is a difficult task. In our opinion, a 
possible solution to this problem is the use of artificial intelligence systems, for example, expert systems $[5,6]$.

The purpose of this article is to consider an alternative approach to determining the size of the SPZ around NFs of I and II hazard classes using expert systems (ES).

\section{DETERMINATION OF SPZ SIZES USING EXPERT SYSTEMS}

Expert systems include a knowledge base (KB), a set of interrelated rules formalizing the experience of specialists in the relevant field of knowledge, and an inference mechanism that allows, based on the rules and a database of necessary databases (DB), to recognize a situation, make a diagnosis or give a recommendation for choosing appropriate actions [5]. It is the expert systems that can combine the information and control functions of radioecological monitoring of the territories where the nuclear power plant is located [7], the data of which must be placed in the DB and form the basis for determining the size of the protective zones around the $\mathrm{NF}$, in particular, the SPZ.

At the NPP Department of the Odessa National Polytechnic University, a program was developed for a personal computer such as IBM PC/AT, which is a simplified version of the ES designed to determine the boundaries of the NPP SPZ [8, 9].

When creating an ES, a frame model of knowledge representation was taken. The basic tool for managing knowledge representation (or memory) and inferences is the object-oriented $\mathrm{C}^{++}$language, built on the principles of object-oriented programming.

The peculiarity of the developed ES lies in the combination of the solution of two problems: diagnostics and control.
The main ES modules are shown in Fig. 1. They contain a package of programs with the help of which the strategy for obtaining the result is implemented. Only the radiation factor of the NPP impact on the environment and population is considered. Non-radiation factors were not taken into account due to the lack of data on the levels of chemical, thermal and electromagnetic effects on the environment and humans near the NPP.

\section{RESULTS OF THE EXPERT SYSTEM APPLICATION FOR DETERMINING SPZ NPP SIZES}

As a radiation criterion for establishing the size of the SPZ, the values of the limits of the annual intake of radioactive substances through the respiratory and digestive organs and the limits of external radiation doses for the reference part of the population. As well as the concentration of radioactive substances in the atmospheric air and on the surface of the earth during normal operation and beyond design basis accidents at NPP.

The dimensions of the SPZ were determined by the distance from the emission source (geometric center of the source group) to the border of the zone, at which the radiation dose limit for the reference part of the population is ensured, both during normal operation of the unit and during an accident.

The dimensions of the SPZ were determined by the distance from the emission source (geometric center of the source group) to the border of the zone, at which the radiation dose limit for the reference part of the population is ensured, both during normal operation of the unit and during an accident.

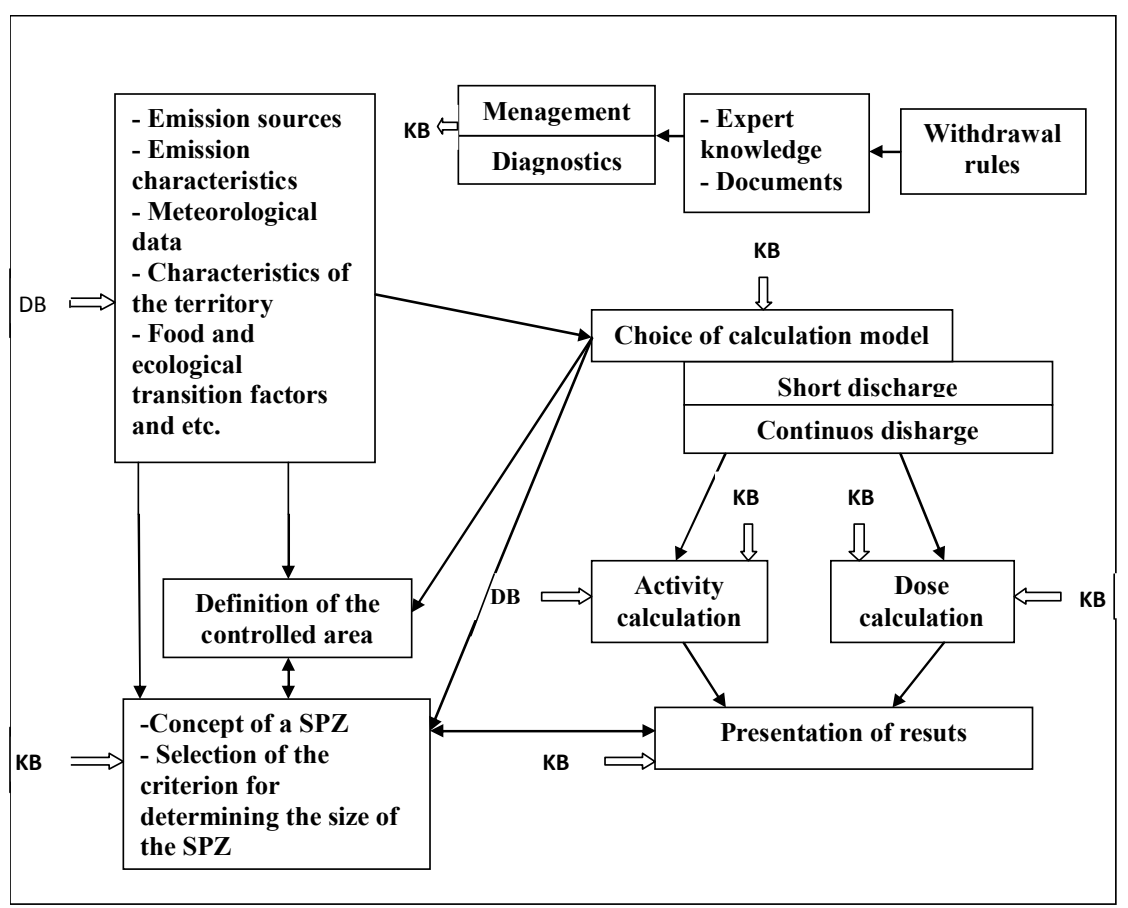

Fig. 1. The main software modules of the expert system for determining the boundaries of the SPZ of NPP

The following time intervals for averaging the emissions of radioactive substances were estimated: instan- taneous (2... $\mathrm{min}$ ), short-term (up to $20 \mathrm{~min}$ ) and averages for a week, a month, and a year. 
The developed ES was applied to assess the size of the Zaporizhzhya NPP (ZNPP) SPZ. For the calculations, the data obtained by the radiation safety service of the Zaporozhzhya NPP during the performance of routine work on radiation monitoring of the environment in 1993 were taken. We also used the results of studies that were carried out within the framework of the program "Substantiation of the environmental safety of construction and operation of the Zaporizhzhya NPP" [10], as well as the results given in [7].

As a result, it was determined that the boundary line of the ZNPP SPZ from the land side is an ellipse with semiaxes $2.5 \times 0.6 \mathrm{~km}$ (Fig. 2), which runs along its coast from the side of the Kakhovskoye reservoir. At present, based on calculations performed in accordance with the NNEGC "Energoatom" standard [4], the ZNPP SPZ is a circle with a radius of $2.5 \mathrm{~km}$.

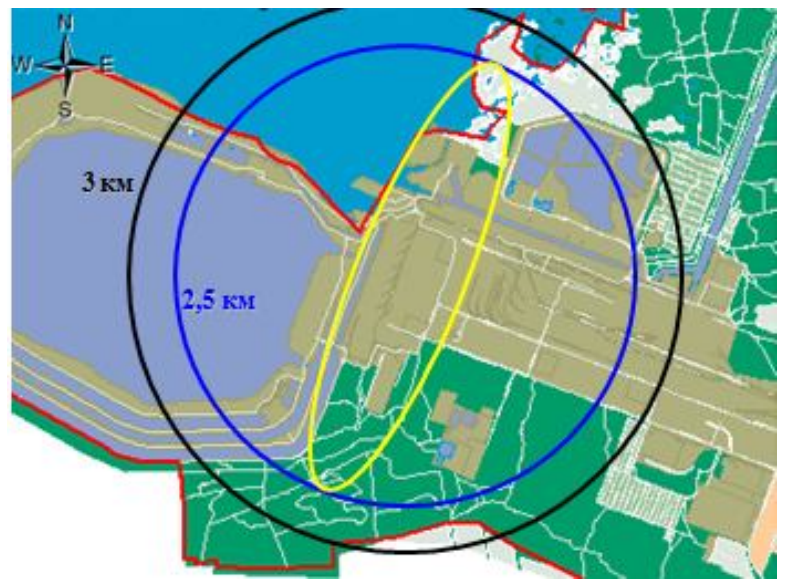

Fig. 2. Sanitary protection zone of Zaporizhzhya NPP: before 2005 (black) - circle $R=3 \mathrm{~km}$; currently (blue) - circle $R=2.5 \mathrm{~km}$; calculation using ES (yellow) - ellips with semiaxes $2.5 \times 0.6 \mathrm{~km}$

\section{CONCLUSIONS}

The main conclusion that can be drawn based on the results obtained using ES is as follows. The size of the NPP SPZ is a variable. In short periods (up to 5 years) depends mainly on the characteristics of the emission from the unit (s) of the plant under the corresponding operating mode. With a longer service life, it depends on the characteristics of the emission and changes in meteorological conditions in the area of the NPP location.

As mentioned above, the impact of a radiation hazardous object on the environment and humans can be caused not only by the radiation factor, but also by factors of a different nature. First of all, this applies to objects of I and II hazard classes. However, it is not yet possible to determine the level of influence of sources of a non-radiation nature on the magnitude of dose loads, the nature of their change under the influence of non-radiation factors and consider this in calculating the size of the SPZ due to the lack of reliable statistically established data.
Nevertheless, despite this situation, in order to improve the accuracy of the results of determining the dimensions of the SPZ, hygienic standards should be applied for all types of exposure to the population (dose limits of exposure, maximum permissible concentration, and maximum permissible level). It seems to us that this recommendation should be reflected in the relevant regulatory documents.

Therefore, the results of determining the dimensions of the SPZ given in the report, with all the errors and the approximation of their obtaining, indicate the possibility and prospects of using expert systems to solve radiation safety problems, in particular, to substantiate the size of the protective zones around the NPP.

\section{REFERENCES}

1. Basic sanitary rules for the protection of radioactive safety in Ukraine. Approved by order of the Ministry of Health of Ukraine dated 02.02.2005, № 54. Registered with the Ministry of Justice of Ukraine on May 20, 2005, № 552/10832.

2. The headquarters of the safety of nuclear power plants. Approved by order of the State Regulatory Agency of Ukraine dated November 19, 2007, № 162. Registered with the Ministry of Justice of Ukraine on January 25, 2008, № 56/14747.

3. IAEA Safety Standards. Preparedness and response in the event of a nuclear or radiological emergency. General safety requirements. No. GSR Part 7. IAEA, Vienna, 2016.

4. SOU NAEK 023:2014. The procedure for establishing the size of the sanitary zone of the NPP. Approved order of DP NAEK Energoatom, № 633 dated 25.07.2014. Agreed: Ministry of Health of Ukraine dated 06.13.2014, № 7.03-58/144/16366; State Inspection of Nuclear Regulation of Ukraine dated January 30, 2014, № 19-11/731.

5. D. Waterman. Guide to expert systems. M.: "Mir", 1989, $388 \mathrm{p}$.

6. E.A. Kamushkin, V.I. Mitin, Yu.M. Semchenkov. Creation of expert systems for nuclear energy // Atomic technology abroad. 1990, № 7, p. 3-8.

7. S.V. Barbashev. System of complex radioecological monitoring of the regions of the location of Ukrainian NPPs: dis. ... Dr. Tech. Sciences. Odessa, 2009, $394 \mathrm{p}$.

8. S.V. Barbashev. Expert system for determining the boundaries of the sanitary protection zone of NPP supervision // Nuclear energy and human safety: 4th Scientific and Technical. Conf. N-Novgorod: NS, 1993, Part 1, p. 89-90.

9. S.V. Barbashev. Artificial intelligence in the examination of the environmental safety of nuclear power plants // Energy: economics, technology, ecology. 1993, № 6, p. 43-45.

10. Zaporizhzhya NPP and the environment. Radioecological state of the observation area in 1993. Issue $1 /$ Compiled and edited by S.V. Barbashev. Odessa, UkrNS, 1994, 72 p.

Article received 06.04.2021 


\section{ПРИМЕНЕНИЕ ЭКСПЕРТНЫХ СИСТЕМ ДЛЯ ОПРЕДЕЛЕНИЯ РАЗМЕРОВ САНИТАРНО-ЗАЩИТНОЙ ЗОНЫ ЯДЕРНЫХ УСТАНОВОК \\ С.В. Барбашев}

Размеры санитарно-защитных зон (СЗ3) для ядерных установок (ЯУ) I и II классов опасности рассчитываются на основании рекомендаций национальных нормативных документов с учетом радиационного фактора воздействия на человека. При этом факторы нерадиационной природы не рассматриваются, хотя они присутствуют в зоне влияния ЯУ и вносят дополнительный вклад в формирование негативных последствий для людей. В этом случае определение границ С33 возможно только в результате анализа, сопоставления и расчета различных величин, характеризующих состояние окружающей среды и ЯУ. Такую возможность может дать применение экспертной системы. Приводятся описание упрощенного варианта экспертной системы, предназначенной для определения границ СЗ3 АЭС, которая учитывает дозовый критерий и критерии по нерадиационным факторам, и результаты ее применения для реальной АЭС.

\section{ЗАСТОСУВАННЯ ЕКСПЕРТНИХ СИСТЕМ ДЛЯ ВИЗНАЧЕННЯ РОЗМІРІВ САНІТАРНО-ЗАХИСНОЇ ЗОНИ ЯДЕРНИХ УСТАНОВОК}

\section{С.В. Барбашев}

Розміри санітарно-захисних зон (С33) для ядерних установок (ЯУ) I і II класів небезпеки розраховуються на підставі рекомендацій національних нормативних документів з урахуванням радіаційного чинника впливу на людину. При цьому чинники нерадіаційної природи не розглядаються, хоча вони присутні в зоні впливу ЯУ і вносять додатковий внесок у формування негативних наслідків для людей. У цьому випадку визначення меж С33 можливе тільки в результаті аналізу, зіставлення і розрахунку різних величин, що характеризують стан навколишнього середовища і ЯУ. Таку можливість може дати застосування експертної системи. Наводяться опис спрощеного варіанту експертної системи, призначеної для визначення меж СЗ3 АЕС, яка враховує дозовий критерій і критерії по нерадіаційних факторах, і результати эї застосування для реальної AEC. 